\title{
DAMPAK IMPLEMENTASI SERTIFIKASI VERIFIKASI LEGALITAS KAYU TERHADAP KEBERLANJUTAN INDUSTRI KAYU DAN HUTAN RAKYAT
}

\author{
(Impacts of Timber Legality Verification System Implementation on the Sustainability of \\ Timber Industry and Private Forest)
}

\author{
Elvida Yosefi Suryandari, Deden Djaenudin, Satria Astana dan Iis Alviya \\ Pusat Penelitian dan Pengembangan Sosial, Eknomi, Kebijakan dan Perubahan Iklim \\ Jalan Gunung Batu No.5, Bogor 16118, Indonesia \\ Email: elvida_ys@yahoo.com; dendja07@yahoo.com.au; astanasatria@yahoo.com; iis_alviya@yahoo.com
}

Diterima 30 Mei 2016, direvisi 22 Maret 2017, disetujui 5 April 2017

\begin{abstract}
International market requires producers to proof the legality of their wood products to address the issues of illegal logging and illegal trade. Timber Legality Verification System (TLVS) has been prepared by the Government of Indonesia that covering the upstream and downstream wood industries. This paper aims to evaluate gaps in the implementation of TLVS policy and its impact on the sustainability of timber industry. This study was using gap, descriptive and costs-structure analyzes. The study was conducted in three provinces, namely: DKI Jakarta, West Java and D.I. Yogyakarta. Research found that the effectiveness of the TLVS implementation was low due to relatively rapid policy changes. This situation became disincetive for investments in timber business. Private sector perceived that TLVS policy should be applied in the upstream of timber business. Hence, the industry and market in the downstream have not been fully support to this system. Furthermore, TLVS policy implementation was considered ineffective by timber industry as well as private forest managers, especially by micro industry and smallholder private forests. This situation threatened the sustainability of timber industry and private forests. Therefore, Institutions should be strengthened in order to improve the quality of human resources and the competitiveness of products.
\end{abstract}

Keywords: Policy impact of TLVS; costs-structure; micro scale industry; private forest.

\begin{abstract}
ABSTRAK
Isu illegal logging dan illegal trading di perdagangan kayu mengakibatkan pasar internasional menuntut bukti legalitas kayu dari produsen. Sistem Verifikasi Legalitas Kayu (SVLK) disiapkan pemerintah secara mengikat di industri kayu mulai dari hulu sampai hilir. Studi ini bertujuan untuk mengetahui gap implementasi kebijakan SVLK dan dampaknya terhadap keberlanjutan usaha industri kayu. Metode yang digunakan yaitu analisis gap, deskriptif dan struktur biaya. Penelitian dilakukan di tiga provisi: DKI Jakarta, Jawa Barat dan DI Yogyakarta. Hasil penelitian menunjukkan bahwa tingkat implementasi SVLK dipandang rendah karena perubahan kebijakan SVLK yang relatif cepat. Bagi dunia usaha kondisi ini merupakan disinsetif bagi iklim investasi. Persepsi pelaku usaha bahwa kebijakan SVLK lebih ditujukan untuk produk dan kegiatan di hulu sehingga kebijakan terkait hilir (industri dan pasar) belum sepenuhnya mendukung. Implementasi kebijakan SVLK dinilai tidak efektif oleh industri kayu dan hutan rakyat. Pihak yang paling besar merasakan dampak negatif SVLK adalah industri mikro dan petani hutan rakyat. Kondisi ini mengancam keberlanjutan industri kayu dan hutan rakyat. Perlu penguatan kelembagaan untuk meningkatkan kualitas sumber daya manusia dan daya saing produk.
\end{abstract}

Kata kunci: Dampak kebijakan SVLK; struktur biaya; industri mikro; hutan rakyat. 


\section{PENDAHULUAN}

Kesadaran masyarakat dunia atas kelestarian dan asal usul kayu telah menjadi tolok ukur penting dalam perdagangan kayu dunia. Isu illegal logging dan illegal trading telah mendorong permintaan kayu di pasar internasional menuntut legalitas kayu dari negara-negara produsen, termasuk Indonesia. Bahkan sejumlah negara konsumen telah memberlakukan regulasi untuk mencegah masuknya kayu illegal, seperti Uni Eropa dengan EU Timber Regulation, Amerika Serikat dengan Lacey Act, dan Australia dengan Australian Prohibition Act. Sebagai salah satu upaya untuk merespon isu tuntutan legalitas kayu di pasar internasional tersebut maka pemerintah Indonesia memberlakukan kebijakan Sistem Verifikasi Legalitas Kayu (SVLK).

Dalam Peraturan Menteri Lingkungan Hidup dan Kehutanan (PermenLHK) Nomor P.95/Menhut-II/2014 tentang Perubahan atas Peraturan Menteri Kehutanan (Permenhut) Nomor P.43/Menhut-II/2014 tentang Penilaian Kinerja Pengelolaan Hutan Produksi Lestari dan Verifikasi Legalitas Kayu pada Pemegang Izin atau pada Hutan Hak, dijelaskan bahwa Sistem Verifikasi Legalitas Kayu (SVLK) adalah suatu sistem yang menjamin kelestarian pengelolaan hutan dan/atau legalitas kayu serta ketelusuran kayu melalui sertifikasi penilaian Pengelolaan Hutan Produksi Lestari (PHPL), sertifikasi Legalitas Kayu (S-LK), dan Deklarasi Kesesuaian Pemasok (DKP). Sistem Verifikasi Legalitas Kayu diterapkan di Indonesia untuk memastikan agar semua produk kayu yang beredar dan diperdagangkan di Indonesia memiliki status legalitas yang meyakinkan, terutama bagi konsumen di luar negeri, sehingga unit manajemen hutan tidak khawatir hasil kayunya diragukan keabsahannya. Demikian pula dengan industri pengolahan kayu, mereka juga lebih yakin terhadap legalitas sumber bahan baku kayunya sehingga lebih mudah meyakinkan para pembelinya di luar negeri.
Sistem SVLK tidak hanya dikenakan pada industri tetapi juga pada hutan rakyat sebagai penghasil kayu rakyat. Implementasi SVLK telah dicanangkan secara mandatori yang berlaku bagi semua skala usaha industri. Namun demikian banyak kendala yang ditemui di lapangan paska kebijakan ini ditetapkan terutama untuk industri skala kecil (Gultom et al., 2014) dan petani hutan rakyat (Susilowati, 2014). Pemerintah telah berupaya untuk menghadapi kendala tersebut dengan kebijakan yang relevan. Namun hingga saat ini masih terdapat gap dalam pelaksanaan kebijakan SVLK antara rencana pelaksanaan dan realitas lapangan.

Tulisan ini bertujuan untuk: (1) Mengetahui gap antara kebijakan dan implementasi SVLK pada industri kayu dan hutan rakyat; dan (2) Mengetahui dampak implementasi kebijakan SVLK terhadap pelaku usaha dan pengelola hutan rakyat.

\section{METODE PENELITIAN}

Implementasi kebijakan SVLK telah ditetapkan secara mandatory yang berlaku mulai pengelolaan hutan hingga perusahaan pengolahan kayu pada tahun 2013. Perusahaan besar secara umum memiliki kapasitas yang memadai untuk melakukan SVLK baik dari kapasitas sumber dayanya maupun biayanya, berbeda dengan Industri Kecil dan Menengah (IKM). Ketika pasokan kayu bulat yang berasal dari hutan alam mengalami penurunan sementara pasokan kayu dari Hutan Tanaman Industri (HTI) belum dapat diandalkan, maka hutan rakyat diharapkan dapat berperan penting sebagai pemasok kayu baik untuk kebutuhan industri dalam negeri maupun ekspor (Effendi, 2011). Bagaimana dampak SVLK terhadap industri besar, sedang, dan kecil yang memanfaatkan kayu dari hutan rakyat menjadi poin yang penting. Klasifikasi industri dibagi dalam empat golongan yaitu: 1. Industri Besar (banyaknya tenaga kerja 100 orang atau lebih) 2. Industri Sedang (banyaknya tenaga kerja 
20-99 orang) 3. Industri Kecil (banyaknya tenaga kerja 5-19 orang) 4. Industri Rumah Tangga/mikro (banyaknya tenaga kerja 1-4 orang) (BPS, 2015b). Berdasarkan data Kementerian Koperasi dan Usaha Kecil Menengah (UKM), rata-rata investasi industri pengolahan pada tahun 2009, 2010 dan 2011 adalah Rp469 juta, Rp493 juta dan Rp421 juta; sedangkan investasi industri mikro jauh di bawah angka tersebut. Sehingga kategori IKM pada Kementerian Perdagangan dapat diasumsikan sama dengan industri mikro dan kecil (berdasarkan tenaga kerja dibawah 20 orang).

Pada kenyataannya suatu kebijakan publik mengadung resiko untuk mengalami kegagalan. Ada tiga faktor yang dapat menyebabkan kegagalan kebijakan, yaitu: (1) Materi atau substansi kebijakan yang buruk (bad policy), (2)Implementasi kebijakan buruk (bad execution) dan (3) Kebijakan bernasib buruk (bad luck) ((Nurrochmat et al., 2016).. Tolok ukur substansi kebijakan yang buruk antara lain: (1) disharmoni kebijakan, (2) inkonsistensi kebijakan, dan ambivalensi kebijakan. Hutan harus dapat menempatkan diri sebagai penyangga kehidupan sekaligus pendorong sektor lainnya. Solusi permasalahan kehutanan tidak hanya dari aspek silvikultur tetapi juga sosiokultural bahkan aspek politik dan ekonomi. Kegagalan atau keberhasilan suatu kebijakan yang mengatur pengelolaan sumber daya alam banyak dipangaruhi oleh aspek ekonomi politik kehutanan (Nurrochmat et al., 2012).

Dampak kebijakan adalah keseluruhan efek yang ditimbulkan oleh suatu kebijakan dalam kondisi kehidupan nyata (Dye, 2008). Menurut Anderson (2003), dampak kebijakan semua bentuk manfaat positif dan biaya, baik yang langsung maupun yang akan datang, secara material (dapat dihitung/ tangible) atau simbolik (intangible). MenurutDye (2008) dan Anderson (2003) terdapat sejumlah dampak kebijakan yang perlu diperhatikan yakni: (1) dampak kebijakan terhadap kelompok target; (2) dampak kebijakan terhadap situasi atau kelompok lain selain situasi atau kelompok target (efek eksternalitas atau spillover); (3) dampak kebijakan terhadap kondisi sekarang dan kondisi masa yang akan datang; dan (4) biaya tidak langsung kebijakan, yang mencakup kehilangan peluang dari kegiatankegiatan lainnya. Tulisan ini membatasi

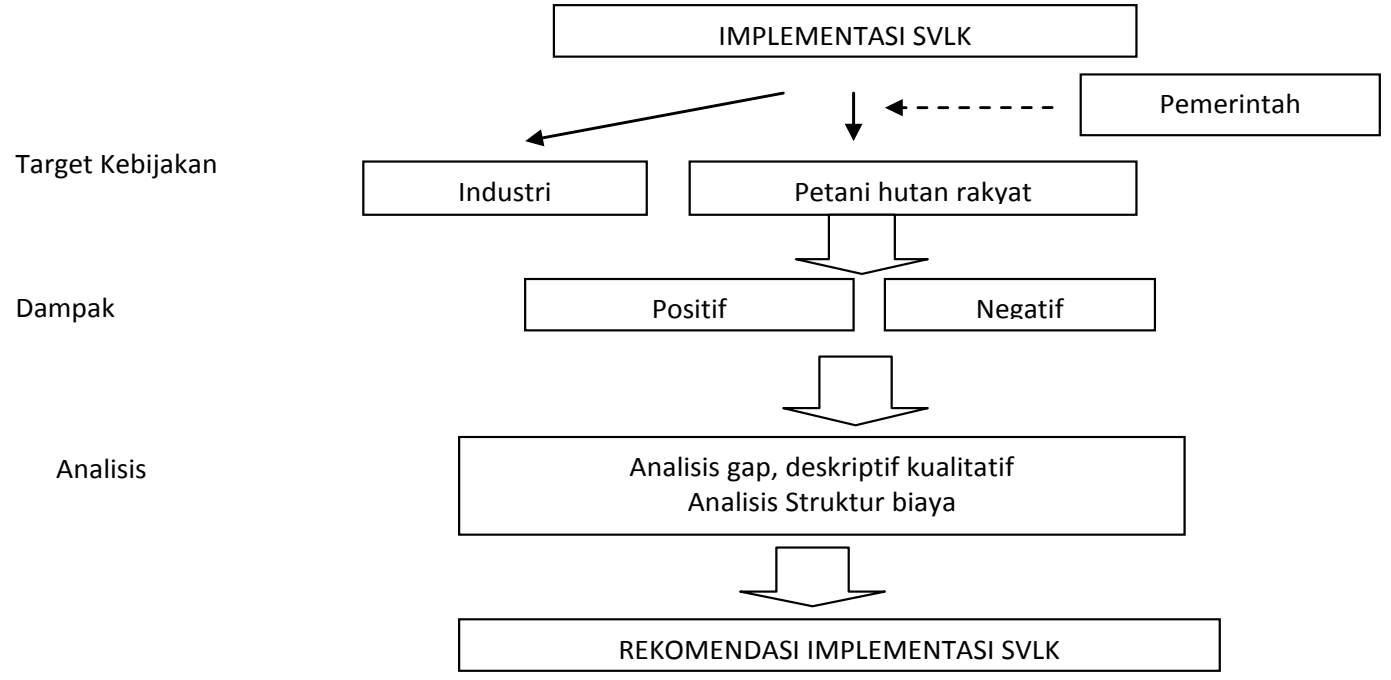

Sumber (Source) : Data primer (Primary data)

Gambar 1. Kerangka pikir penelitian

Figure 1. Logical framework of research 
Tabel 1. Peraturan tentang SVLK

Table 1. Regulations on TVLS

\begin{tabular}{|c|c|c|c|}
\hline No & $\begin{array}{l}\text { Peraturan } \\
\text { (Regulations) }\end{array}$ & $\begin{array}{c}\text { Perihal } \\
(\text { In terms })\end{array}$ & $\begin{array}{c}\text { Diskripsi } \\
\text { (Description) }\end{array}$ \\
\hline 1 & $\begin{array}{l}\text { Peraturan } \\
\text { Pemerintah } \\
\text { Nomor } 6 \\
\text { Tahun } 2007 \\
\text { jo. Peraturan } \\
\text { Pemerintah } \\
\text { Nomor } 3 \text { Tahun } \\
2008\end{array}$ & $\begin{array}{l}\text { Tata Hutan dan } \\
\text { Penyusunan Rencana } \\
\text { Pengelolaan Hutan, serta } \\
\text { Pemanfaatan Hutan }\end{array}$ & $\begin{array}{l}\text { - Pasal } 125 \text { ayat (3) bahwa keberhasilan pengelolaan hutan } \\
\text { lestari dicerminkan dari kinerja pemegang Izin Usaha } \\
\text { Pemanfaatan Hasil Hutan (IUPHH) } \\
\text { - Pasal } 100 \text { pemanfaatan hutan rakyat bertujuan untuk } \\
\text { memperoleh manfaat yang optimal dengan tidak } \\
\text { mengurangi fungsinya; } \\
\text { - Pasal } 119 \text { setiap pengangkutan, penguasaan atau } \\
\text { pemilikan hasil hutan yang berasal dari Hutan Negara, } \\
\text { wajib dilengkapi bersama-sama dengan dokumen yang } \\
\text { merupakan sahnya hasil hutan }\end{array}$ \\
\hline 2 & $\begin{array}{l}\text { Permenhut } \\
\text { Nomor P.38/ } \\
\text { Menhut- } \\
\text { II/2009 }\end{array}$ & $\begin{array}{l}\text { Standard dan Pedoman } \\
\text { Penilaian Kinerja } \\
\text { Pengelolaan Hutan } \\
\text { Produksi Lestari dan } \\
\text { Verifikasi Legalitas Kayu } \\
\text { pada Pemegang Izin atau } \\
\text { pada Hutan Rakyat }\end{array}$ & $\begin{array}{l}\text { - Dalam rangka menuju Pengelolaan Hutan Produksi } \\
\text { Lestari (PHPL), serta penerapan tata kelola kehutanan, } \\
\text { pemberantasan penebangan liar dan perdagangannya, } \\
\text { perlu ditetapkan Standard Pedoman Penilaian Kinerja } \\
\text { Pengelolaan Hutan Produksi Lestari dan Verifikasi } \\
\text { Legalitas Kayu Pada Pemegang Izin Atau pada Hutan } \\
\text { rakyat, dengan Peraturan Menteri Kehutanan }\end{array}$ \\
\hline 3 & $\begin{array}{l}\text { Permenhut } \\
\text { Nomor P.68/ } \\
\text { Menhut-II/2011 }\end{array}$ & $\begin{array}{l}\text { Perubahan Atas Permenhut } \\
\text { Nomor P.38/Menhut- } \\
\text { II/2009 Tentang Standar } \\
\text { dan Pedoman Penilaian } \\
\text { Kinerja Pengelolaan Hutan } \\
\text { Produksi Lestari dan } \\
\text { Verifikasi Legalitas Kayu } \\
\text { pada Pemegang Izin Atau } \\
\text { Pada Hutan Rakyat }\end{array}$ & $\begin{array}{l}\text { - Untuk lebih menjamin kepastian hukum dan usaha } \\
\text { - Pemegang Ijin Usaha Pemanfaatan Hasil Hutan Kayu- } \\
\text { Hutan Tanaman Rakyat ( IUPHHK-HTR), Ijin Usaha } \\
\text { Pemanfaatan Hasil Hutan Kayu-Hutan Kemasyarakatan } \\
\text { (IUPHHK-HKm), Ijin Usaha Pemanfaatan Hasil Hutan } \\
\text { Kayu-Hutan Desa (IUPHHK-HD), Ijin Usaha Industri } \\
\text { Pemanfaatan Hasil Hutan Kayu (IUIPHHK) dengan } \\
\text { kapasitas sampai dengan } 2.000 \mathrm{~m}^{3} \text { per tahun, Tanda } \\
\text { Daftar Industri (TDI), termasuk industri rumah tangga/ } \\
\text { pengrajin dan pedagang ekspor, atau pemilik hutan } \\
\text { rakyat, dapat mengajukan verifikasi legalitas kayu (LK) } \\
\text { secara kolektif }\end{array}$ \\
\hline 4 & $\begin{array}{l}\text { Permendag } \\
\text { Nomor } 64 \\
\text { /M-DAG/ } \\
\text { PER/10/2012 }\end{array}$ & $\begin{array}{l}\text { Ketentuan Ekspor Produk } \\
\text { Industri Kehutanan }\end{array}$ & $\begin{array}{l}\text { - Untuk mendukung hilirisasi industri kehutanan perlu } \\
\text { sumber bahan baku legal dan dikelola secara lestari } \\
\text { Ekspor dapat dilaksanakan oleh industri yang terdaftar } \\
\text { dalam Eksportir Terdaftar Produk Industri Kehutanan } \\
\text { (ETPIK) } \\
\text { - Dokumen V-Legal wajib untuk panel, woodworking, } \\
\text { bangunan prefabs, sebagian pulp dan kertas }\end{array}$ \\
\hline 5 & $\begin{array}{l}\text { Permenhut } \\
\text { Nomor P.45/ } \\
\text { Menhut- } \\
\text { II/2012 }\end{array}$ & $\begin{array}{l}\text { Perubahan Kedua atas } \\
\text { Permenhut Nomor P.38/ } \\
\text { Menhut-II/2009 Tentang } \\
\text { Standar dan Pedoman } \\
\text { Penilaian Kinerja } \\
\text { Pengelolaan Hutan } \\
\text { Produksi Lestari dan } \\
\text { Verifikasi Legalitas Kayu } \\
\text { pada Pemegang Izin atau } \\
\text { pada Hutan Rakyat }\end{array}$ & $\begin{array}{l}\text { - Pemegang IUIPHHK yang mempunyai keterkaitan } \\
\text { bahan baku hutan rakyat, wajib memfasilitasi pemilik } \\
\text { hutan rakyat untuk memperoleh Sertifikat Legalitas } \\
\text { Kayu (S-LK). S-LK tersebut berlaku selama } 10 \text { tahun } \\
\text { dan dilakukan penilikan } 24 \text { bulan sekali. } \\
\text { - Pemegang IUPHHK-HTR, IUPHHK-HKm, IUPHHK- } \\
\text { HD, IUIPHHK hingga } 2.000 \mathrm{~m}^{3} / \text { thn, TDI, Ijin Usaha } \\
\text { Industri (IUI) dengan investasi sampai Rp500.000.000 } \\
\text { di luar tanah dan bangunan, termasuk industri rumah } \\
\text { tangga/pengrajin dan pedagang ekspor, pengajukan } \\
\text { verifikasi LK secara kelompok. } \\
\text { Pelaksanaannya pembiayaan pendampingan dan } \\
\text { verifikasi legalitas kayu periode ke-1 (anggaran KLHK) } \\
\text { dilakukan secara berkelompok }\end{array}$ \\
\hline
\end{tabular}




\begin{tabular}{|c|c|c|c|}
\hline No & $\begin{array}{l}\text { Peraturan } \\
\text { (Regulations) }\end{array}$ & $\begin{array}{l}\text { Perihal } \\
\text { (In terms) }\end{array}$ & $\begin{array}{c}\text { Diskripsi } \\
\text { (Description) }\end{array}$ \\
\hline & & & $\begin{array}{l}\text { - Sertifikat PHPL bagi pemegang Ijin Usaha Pemanfaatan } \\
\text { Hasil Hutan Kayu- Hutan Alam/Hutan Tanaman/ } \\
\text { Restorasi Ekosistem (IUPHHK-HA/HT/RE/) pemegang } \\
\text { hak pengelolaan berlaku selama } 5 \text { tahun sejak diterbitkan } \\
\text { dan dilakukan penilikan sekurang-kurangnya } 1 \text { tahun } \\
\text { sekali. } \\
\text { - Sertifikat LK bagi pemegang IUPHHK-HA/HT/RE/ } \\
\text { hak pengelolaan, IUPHHK-HTR/HKM/HD/HTHR/ } \\
\text { IPK, IUIPHHK, IUI dengan modal investasi lebih dari } \\
\text { Rp500.000.000 di luar tanah dan bangunan, pedagang } \\
\text { ekspor, hutan rakyat dan Tempat Penampungan Terdaftar } \\
\text { (TPT) berlaku selama } 3 \text { tahun sejak diterbitkan dan } \\
\text { dilakukan penilikan sekurang-kurangnya } 1 \text { tahun sekali. } \\
\text { Sertifikat LK bagi IUI dengan investasi sampai dengan } \\
\text { Rp500.000.000 di luar tanah dan bangunan, TDI dan } \\
\text { industri rumah tangga/pengrajin berlaku } 6 \text { tahun dan } \\
\text { dilakukan penilikan sekurang-kurangnya } 24 \text { bulan sekali. }\end{array}$ \\
\hline 6 & $\begin{array}{l}\text { Permenhut } \\
\text { Nomor P.42/ } \\
\text { Menhut- } \\
\text { II/2013 }\end{array}$ & $\begin{array}{l}\text { Perubahan Ketiga Atas } \\
\text { Permenhut Nomor P.38/ } \\
\text { Menhut-II/2009 Tentang } \\
\text { Standar Dan Pedoman } \\
\text { Penilaian Kinerja } \\
\text { Pengelolaan Hutan } \\
\text { Produksi Lestari dan } \\
\text { Verifikasi Legalitas Kayu }\end{array}$ & $\begin{array}{l}\text { - Berdasarkan hasil evaluasi dan untuk lebih menjamin } \\
\text { kepastian hukum maka perlu menetapkan Peraturan } \\
\text { Menteri Kehutanan tentang Perubahan Ketiga Atas } \\
\text { Peraturan Menteri Kehutanan Nomor P.38/Menhut- } \\
\text { II/2009 tentang Standard dan Pedoman Penilaian Kinerja } \\
\text { Pengelolaan Hutan Produksi Lestari dan Verifikasi } \\
\text { Legalitas Kayu pada Pemegang Izin atau pada Hutan } \\
\text { rakyat }\end{array}$ \\
\hline
\end{tabular}
pada Pemegang Izin atau Pada Hutan Rakyat

\begin{tabular}{|c|c|c|c|}
\hline 7 & $\begin{array}{l}\text { Permendag } \\
\text { Nomor } \\
\text { 81/M-DAG/ } \\
\text { PER/122013 }\end{array}$ & $\begin{array}{l}\text { Perubahan tentang } \\
\text { Ketentuan Ekspor Produk } \\
\text { Industri Kehutanan }\end{array}$ & 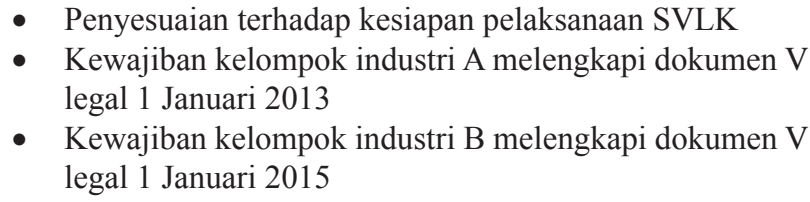 \\
\hline 8 & $\begin{array}{l}\text { Permenhut } \\
\text { Nomor P.43/ } \\
\text { Menhut-II/ } \\
2014\end{array}$ & $\begin{array}{l}\text { Penilaian Kinerja } \\
\text { Pengelolaan Hutan } \\
\text { Produksi Lestari dan } \\
\text { Verifikasi Legalitas Kayu } \\
\text { pada Pemegang Izin atau } \\
\text { pemilikHutan Rakyat }\end{array}$ & $\begin{array}{l}\text { - Perkembangan kinerja pengelolaan hutan produksi } \\
\text { hutan produksi lestari dan verifikasi legalitas kayu, maka } \\
\text { perlu dilakukan pengaturan kembali penilaian kinerja } \\
\text { pengelolaan hutan produksi lestari dan verifikasi legalitas } \\
\text { kayu pada pemegang izin atau pada hutan rakyat }\end{array}$ \\
\hline 9 & $\begin{array}{l}\text { PermenLHK } \\
\text { Nomor P.95/ } \\
\text { Menhut- } \\
\text { II/2014 }\end{array}$ & $\begin{array}{l}\text { Perubahan atas Permenhut } \\
\text { Nomor } \\
\text { P.43/Menhut-II/2014 } \\
\text { Tentang Penilaian Kinerja } \\
\text { Pengelolaan Hutan } \\
\text { Produksi Lestari dan } \\
\text { Verifikasi } \\
\text { Legalitas Kayu pada } \\
\text { Pemegang Izin atau } \\
\text { pemilik hutan rakyat }\end{array}$ & $\begin{array}{l}\text { - Terdapat hambatan bagi industri kecil dan menengah } \\
\text { Pemilik hutan rakyat, IUIPHHK kapasitas sampai } \\
6.000 \mathrm{~m}^{3} / \text { tahun, Industri Kecil Menengah ( IKM), } \\
\text { TPT, Industri Rumah Tangga/Pengrajin diberikan } \\
\text { kesempatan untuk memperoleh pembinaan dan fasilitasi } \\
\text { pemerintah (ketrampilan teknis, pembinaan, sertifikasi } \\
\text { berkelompok, pembiayaan sertifikasi dan penilikan } \\
\text { pertama) } \\
\text { Pemegang ETPIK IKM Mebel yang belum atau sudah } \\
\text { memiliki S-LK yang bahan baku produk olahannya } \\
\text { belum memiliki S-LK atau Deklarasi Kesesuaian } \\
\text { Pemasok ( DKP), untuk ekspor menggunakan Deklarasi } \\
\text { Ekspor sampai dengan } 31 \text { Desember } 2015 \text {. } \\
\text { Deklarasi Ekspor adalah pernyataan dari IKM pemilik } \\
\text { ETPIK bahwa barang yang diekspor menggunakan } \\
\text { sumber bahan baku yang telah memenuhi persyaratan } \\
\text { legalitas }\end{array}$ \\
\hline
\end{tabular}




\begin{tabular}{|c|c|c|c|}
\hline No & $\begin{array}{l}\text { Peraturan } \\
\text { (Regulations) }\end{array}$ & $\begin{array}{c}\text { Perihal } \\
\text { (In terms) }\end{array}$ & $\begin{array}{c}\text { Diskripsi } \\
\text { (Description) }\end{array}$ \\
\hline 10 & $\begin{array}{l}\text { Permendag Nomor } \\
\text { 97/M-DAG/ } \\
\text { PER/12/2014 }\end{array}$ & $\begin{array}{l}\text { Perubahan tentang } \\
\text { Ketentuan Ekspor Produk } \\
\text { Industri Kehutanan }\end{array}$ & $\begin{array}{l}\text { Definisi IKM pemilik ETPIK adalah industri } \\
\text { pemilik Tanda Daftar Industri (TDI) dan Izin Usaha } \\
\text { Industri (IUI) yang telah mendapat pengakuan } \\
\text { sebagai ETPIK tetapi belum memiliki Sertifikat } \\
\text { Legalitas Kayu (S-LK) dengan batasan nilai } \\
\text { investasi sampai dengan Rp } 10 \text { miliar } \\
\text { Dokumen V-Legal wajib untuk panel, woodworking, } \\
\text { bangunan prefabs, sebagian pulp dan kertas serta } \\
\text { furniture dan kerajinan untuk pelaku usaha besar. } \\
\text { Untuk IKM furniture menggunakan Deklarasi } \\
\text { Ekspor. }\end{array}$ \\
\hline 11 & $\begin{array}{l}\text { PermenLHK } \\
\text { Nomor P.96/ } \\
\text { Menhut-II/2014 }\end{array}$ & $\begin{array}{l}\text { Perubahan Permenhut } \\
\text { Nomor } \\
\text { P.13/Menhut-II/2013 } \\
\text { tentang Standar Biaya } \\
\text { Penilaian Kinerja } \\
\text { Pengelolaan Hutan } \\
\text { Produksi Lestari } \\
\text { dan Verifikasi Legalitas } \\
\text { Kayu }\end{array}$ & $\begin{array}{l}\text { Penetapan ulang standar Biaya Penilaian Kinerja } \\
\text { Pengelolaan Hutan Produksi Lestari dan Verifikasi } \\
\text { Legalitas Kayu : industri rumah tangga/pengrajin, } \\
\text { TDI/IUI }<500 \text { juta, IUPHHK }<2.000 \mathrm{~m}^{3} \text {,IUPHHK } \\
2.000-6.000 \mathrm{~m}^{3} \text {, IUI dan IUPHHK }>6.000 \mathrm{~m}^{3} \text {, dan } \\
\text { TPT }\end{array}$ \\
\hline 12 & $\begin{array}{l}\text { PermendagNomor } \\
66 / \text { M-DAG/PER/8/ } \\
2015\end{array}$ & $\begin{array}{l}\text { Perubahan beberapa } \\
\text { ketentuan Permendag } \\
\text { RI No. 97/M-DAG/ } \\
\text { PER/12/2014 tentang } \\
\text { Ketentuan Ekspor Produk } \\
\text { Industri Kehutanan }\end{array}$ & $\begin{array}{l}\text { - Permendag ini memungkinkan pengekspor cukup } \\
\text { hanya memiliki Deklarasi Ekspor (DE) untuk } \\
\text { melakukan ekspor tanpa batas waktu }\end{array}$ \\
\hline 13 & $\begin{array}{l}\text { Permendag Nomor } \\
\text { 89/M-DAG/ } \\
\text { PER/10/ } 2015\end{array}$ & $\begin{array}{l}\text { Perubahan beberapa } \\
\text { ketentuan Permendag } \\
\text { RI No. 97/M-DAG/ } \\
\text { PER/12/2014 jo } \\
\text { Permendag Nomor } \\
\text { 66/M-DAG/PER/8/ } \\
\text { 2015 tentang Ketentuan } \\
\text { Ekspor Produk Industri } \\
\text { Kehutanan; }\end{array}$ & $\begin{array}{l}\text { Dokumen V-Legal wajib untuk panel, woodworking, } \\
\text { bangunan prefabs, sebagian pulp dan kertas serta } \\
\text { tidak untuk furniture dan kerajinan }\end{array}$ \\
\hline 14 & $\begin{array}{l}\text { PermenLHK } \\
\text { Nomor P30/ } \\
\text { Menlhk/Setjen/ } \\
\text { PHPL.3/3/2016 }\end{array}$ & $\begin{array}{l}\text { Penilaian Kinerja } \\
\text { Pengelolaan hutan } \\
\text { Produksi Lestari dan } \\
\text { Verifikasi Legalitas Kayu } \\
\text { pada pemegang Izin, Hak } \\
\text { Pengelolaan atau Hutan } \\
\text { Hak }\end{array}$ & $\begin{array}{l}\text { Mengurangi hambatan pelaku usaha seperti jangka } \\
\text { waktu sertifikasi, pemenuhan kewajiban bahan baku } \\
\text { sertifikasi dan peningkatan penerimaan pasar }\end{array}$ \\
\hline 15 & $\begin{array}{l}\text { Permendag Nomor } \\
\text { 25/M-DAG/PER/4/ } \\
2016\end{array}$ & $\begin{array}{l}\text { Perubahan atas Permendag } \\
\text { Nomor 89/M-DAG/ } \\
\text { PER/10/ 2015 tentang } \\
\text { Ketentuan Ekspor Produk } \\
\text { Industri Kehutanan }\end{array}$ & - Furniture dan kerajinan wajib dokumen V legal \\
\hline
\end{tabular}

Sumber (Source): Data sekunder diolah (Secondary data processed) 
dampak terhadap kelompok target/non target maupun dampak kebijakan saat ini secara langsung dan yang dapat dihitung terhadap keberlanjutan industri dan pengelolaan hutan rakyat.

Analisis yang digunakan adalah analisis gap, analisis deskriptif kualitatif dan analisis struktur biaya. Suatu keadaan dimana dalam suatu proses kebijakan selalu terbuka kemungkinan terjadinya perbedaan antara apa yang diharapkan pembuat kebijakan dengan apa yang kenyataannya dicapai (sebagai hasil impelementasi kebijakan) (Wahab dalam LAN, 2008). Analisis gap untuk melihat kesenjangan antara aturan yang telah ditetapkan dan implementasinya di daerah. Lebih lanjut menurut Nurrochmat et al. (2016) kesesuaian suatu kebijakan tidak hanya dilihat dari materi muatan dan hirarki, tetapi menyangkut suatu implementasi kebijakan yang dikaji secara bersama-sama. Analisis deskriptif kualitatif untuk melihat dampak pelaksanaan SVLK secara menyeluruh baik sisi positif (menguntungkan) dan negatif (merugikan). Sementara analisis struktur biaya dilakukan untuk mengetahui biaya yang diperlukan oleh industri dan hutan rakyat. Lebih lanjut untuk mengetahui keberlanjutan produksi industri dan hutan rakyat ke depan pasca pemberlakukan SVLK.

Lokasi penelitian di DKI Jakarta, Jawa Barat dan DI Yogyakarta, pengambilan data dilakukan mulai 19 April 2016 sampai dengan 23 September 2016. DKI Jakarta untuk mendapatkan data sekunder terkait peraturan perundangan dan wawancara dengan stakeholder terkait. Jawa Barat dan DI Yogyakarta merupakan sentra produksi kayu rakyat sekaligus industri pengolahan kayu.

\section{HASIL DAN PEMBAHASAN}

\section{A. Gap Kebijakan dan Implementasi SVLK}

Sistem Verifikasi Legalitas Kayu (SVLK) adalah forest certification dan sistem penjaminan legalitas kayu Indonesia yang dibangun dan dikembangkan oleh multistakeholder sejak tahun 2003. Tujuan SVLK untuk memberantas illegal logging yang terjadi di Indonesia, mempromosikan kayu legal yang berasal dari sumber yang lestari, perbaikan tata kelola kehutanan dan meningkatkan martabat bangsa dan kesejahteraan rakyat. Melalui pembahasan yang panjang, SVLK ditetapkan sebagai sebuah kebijakan sejak tahun 2009 melalui Peraturan Menteri Kehutanan (Permenhut) Nomor P.38/Menhut-II/2009 jo Peraturan Menteri Lingkungan Hidup dan Kehutanan (PermenLHK) Nomor P.95/Menhut-II/2014 tentang Standar dan Pedoman Penilaian Kinerja Pengelolaan Hutan Produksi Lestari dan Verifikasi Legalitas Kayu pada Pemegang Izin atau pada Hutan Hak.

Berdasarkan pada kesepakatan multistakeholder, SVLK bersifat wajib (mandatory) dan telah diimplementasikan secara penuh sejak 1 Januari 2013. Setiap pelaksanaan ekspor produk industri kehutanan untuk Harmonized System (HS) Code yang ditetapkan berdasarkan peraturan menteri perdagangan, wajib menggunakan Dokumen V-Legal. Berikut diuraikan peraturan terkait dan mengatur mengenai SVLK seperti Tabel 2.

Berdasarkan Tabel 2 terlihat bahwa terdapat perbedaan standar biaya pada kedua kebijakan tersebut. Kementerian LHK berusaha untuk melakukan perbaikan kebijakan terkait standar biaya. PermenLHK Nomor P.96/Menhut-II/2014 merupakan merupakan koreksi atas standar biaya pada peraturan sebelumnya (Permenhut Nomor P.13/Menhut-II/2013), sehingga diharapkan dapat membantu meringankan industri kecil dan menengah dalam proses mendapatkan SVLK.

Kebijakan SVLK baik yang dikeluarkan oleh Kementerian LHK maupun Kementerian Perdagangan menunjukkan perubahan yang dinamis (cepat), sementara pengguna kebijakan (industri dan hutan rakyat) cenderung lambat dan masih dalam tahap awal 
Tabel 2. Perbedaan antara Permenhut Nomor P.13/Menhut-II/2013 dan PermenLHK Nomor P.96/Menhut-II/2014 Table 2. Difference between Permenhut Nomor P.13/Menhut-II/2013 dan PermenLHK Nomor P.96/Menhut-II/2014

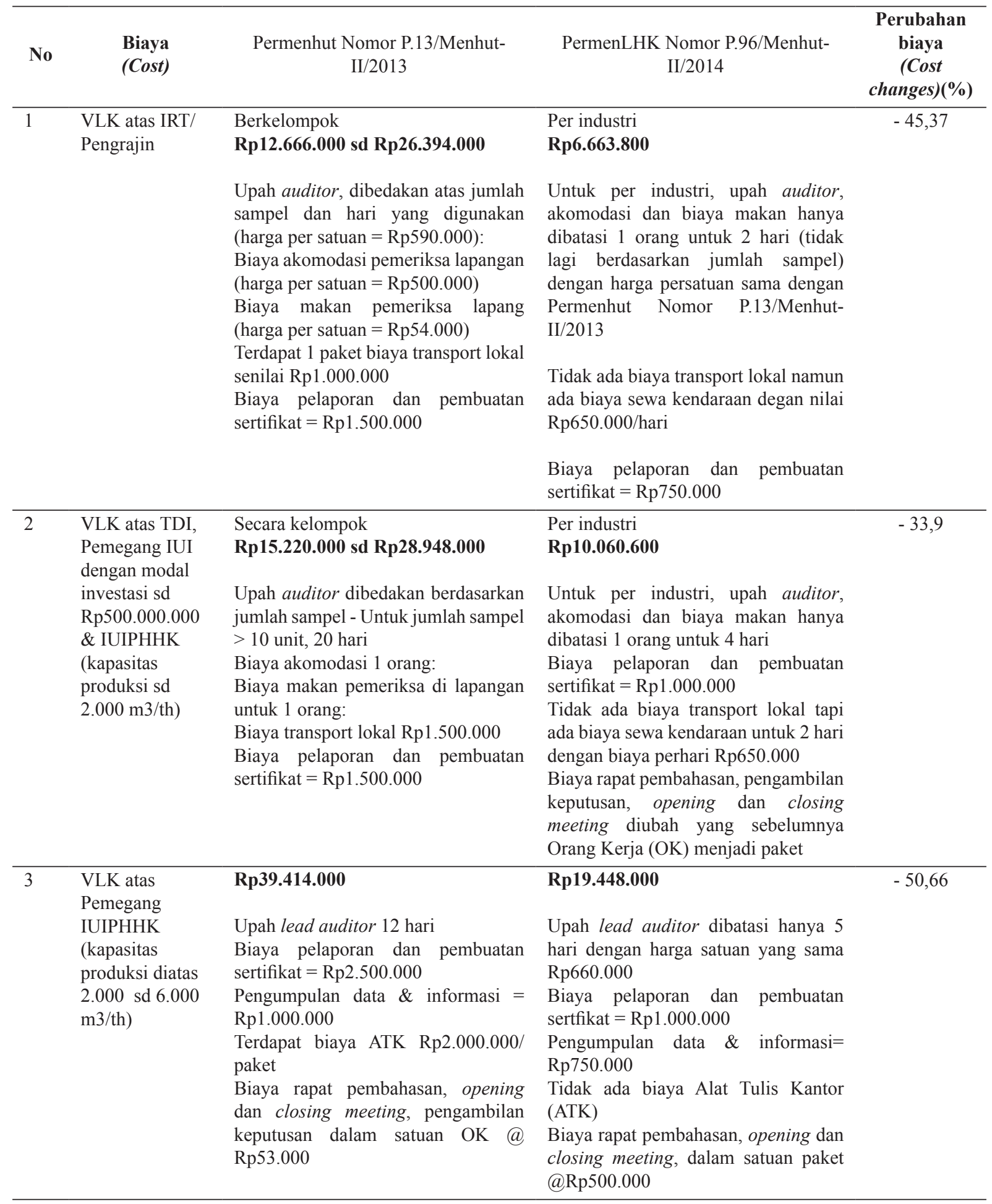




\begin{tabular}{|c|c|c|c|c|}
\hline No & $\begin{array}{l}\text { Biaya } \\
\text { (Cost) }\end{array}$ & $\begin{array}{l}\text { Permenhut Nomor P.13/Menhut- } \\
\text { II/2013 }\end{array}$ & $\begin{array}{l}\text { PermenLHK Nomor P.96/Menhut- } \\
\text { II/2014 }\end{array}$ & $\begin{array}{c}\text { Perubahan } \\
\text { biaya } \\
\text { (Cost } \\
\text { changes) }(\%)\end{array}$ \\
\hline 4 & $\begin{array}{l}\text { VLK atas } \\
\text { Pemegang } \\
\text { IUIPHHK } \\
\text { (kapasitas } \\
\text { produksi diatas } \\
6.000 \mathrm{~m} 3 / \mathrm{th} \text { ) }\end{array}$ & $\begin{array}{l}\text { Rp49.354.000 } \\
\text { Upah lead auditor } 14 \text { hari } \\
\text { Biaya pelaporan dan pembuatan } \\
\text { sertifikat = Rp3.000.000 } \\
\text { Pengumpulan data \& informasi = } \\
\text { Rp1.500.000 } \\
\text { Terdapat biaya ATK Rp2.500.00 } \\
\text { Biaya transport lokal untuk14 hari @ } \\
\text { Rp600.000 } \\
\text { Biaya rapat pembahasan, dalam } \\
\text { satuan OK @Rp53.000 }\end{array}$ & $\begin{array}{l}\text { Rp28.879.400 } \\
\text { Upah lead auditor } 8 \text { hari } \\
\text { Biaya pelaporan dan pembuatan } \\
\text { sertifikat = Rp1.500.000 } \\
\text { Pengumpulan data = Rp1.000.000 } \\
\text { Tidak ada biaya ATK } \\
\text { Biaya sewa kendaraan untuk } 3 \text { hari @ } \\
\text { Rp650.000 } \\
\text { Biaya rapat pembahasan, dalam satuan } \\
\text { paket @Rp500.000 }\end{array}$ & $-41,49$ \\
\hline 5 & VLK atas TPT & $\begin{array}{l}\text { Rp 13.663.000 } \\
\text { Ada upah administrator dan operator } \\
1 \text { orang } 7 \text { hari } \\
\text { Pengumpulan data \& informasi = } \\
\text { Rp1.000.000 } \\
\text { Biaya pelaporan dan pembuatan } \\
\text { sertifikat = Rp2.500.000 } \\
\text { Biaya ATK Rp2.000.000/paket } \\
\text { Transport lokal } 2 \text { hari @Rp600.000 } \\
\text { Biaya rapat pembahasan, opening } \\
\text { dan closing meeting, satuan OK @ } \\
\text { Rp53.000 }\end{array}$ & $\begin{array}{l}\text { Rp 9.389.600 } \\
\text { Tidak ada upah administrator dan } \\
\text { operator } \\
\text { Pengumpulan data }=\text { Rp } 500.000 \\
\text { Biaya pelaporan /pembuatan sertifikat } \\
=\text { Rp1.000.000 } \\
\text { Tidak ada biaya ATK } \\
\text { Biaya rapat pembahasan, opening } \\
\text { dan closing meeting, pengambilan } \\
\text { keputusan diubah dalam satuan paket } \\
\text { @ Rp500.000 }\end{array}$ & $-31,28$ \\
\hline
\end{tabular}

Sumber (Source) : Data sekunder diolah (Secondary data processed)

untuk mengadopsi kebijakan SVLK, bahkan ada yang belum paham tentang kebijakan tersebut. Kebijakan yang terlalu cepat berubah, pada akhirnya, membingungkan pengguna atau bahkan memicu untuk tidak mengadopsi kebijakan tersebut.

Dalam Permenhut Nomor P.45/MenhutII/2012 ada kerancuan antara pasal 4 ayat $4 \mathrm{~b}$ dengan pasal pasal 10 ayat (4) tentang masa berlaku sertifikat dan penilikan. Pada pasal 4 ayat $4 \mathrm{~b}$ dinyatakan bahwa S-LK pada hutan rakyat berlaku selama 10 tahun dan dilakukan penilikan sekurang-kurangnya 24 bulan sekali. Sementara pada pasal 10 ayat (4) dinyatakan bahwa masa berlaku SLK pada hutan rakyat adalah selama 3 tahun dan dilakukan penilikan sekurang-kurangnya setiap 12 bulan. Ketidakkonsistenan peraturan tersebut tersebut diperbaiki pada peraturan Permenhut Nomor P.42/Menhut-II/2013 yang merupakan perubahan terhadap Permenhut Nomor P.45/ Menhut-II/2012 dimana pada pasal pasal
10 ayat (4) redaksional 'hutan rakyat'nya dihapus menjadi:"Sertifikat LK bagi pemegang IUPHHK-HA/HT/RE/pemegang hak pengelolaan, IUPHHK-HTR/HKM/HD/ HTHR/IPK, IUIPHHK, IUI dengan modal investasi lebih dari Rp500.000.000 di luar tanah dan bangunan, dan TPT berlaku selama tiga tahun sejak diterbitkan dan dilakukan penilikan (surveillance) sekurang-kurangnya 12 bulan sekali." (kalimat: pedagang ekspor, pemilik hutan rakyat dihapus). Kemudian pada ayat (6) menjadi:

"Sertifikat LK bagi IUI dengan investasi sampai dengan Rp500.000.000 di luar tanah dan bangunan, TDI dan industri rumah tangga/pengrajin dan pedagang ekspor berlaku selama 6 tahun sejak diterbitkan dan dilakukan penilikan (surveillance) sekurangkurangnya 24 bulan sekali." (ada penambahan kata pedagang ekspor).

Dengan demikian masa berlaku SLK dan penilikannya pada hutan rakyat tetap 
mengacu Permenhut Nomor P.45/MenhutII/2012Pasal 4 Ayat (4b) yaitu 10 tahun dengan masa penilikan setiap 24 bulan sekali. Kementerian LHK lebih menitikberatkan pada bagian hulu (sumber bahan baku kayu) yang memiliki kewenangan pada pengelolaan hutan dan telah berusaha untuk mengurangi hambatan untuk industri kecil baik segi biaya maupun teknis. Kementerian LHK menerbitkan P.95/Menhut-II/2014 untuk mengurangi hambatan pada industri kecil dan menengah dan memberikan kesempatan untuk memperoleh pembinaan dan fasilitasi pemerintah (ketrampilan teknis, pembinaan, sertifikasi berkelompok, pembiayaan sertifikasi dan penilikan pertama). Sertifikat secara kelompok bagi IKM dengan masa berlaku sertifikat dari 3 tahun menjadi 6 tahun dan surveillance dari setahun menjadi 2 tahun. Pembiayaan sertifikasi dan pendampingan untuk IKM telah disediakan oleh Kementerian LHK bersama Multistakeholder Forestry Programme (MFP) sebanyak 33,4 Miliar tahun 2015. Kementerian Perindustrian mengalokasikan anggaran untuk IKM sebesar Rp5 miliar (Kementerian Perindustrian, 2015). Memberikan keringanan dokumen keterangan legalitas bahan baku melalui penggunaan Deklarasi Kesesuaian Pemasok (DKP ) dimana dokumen ini diterbitkan sendiri oleh pelaku usaha sesuai dengan sumber bahan bakunya.

Sementara kebijakan di bidang hilir yang merupakan ranah Kementerian Perdagangan cenderung melemahkan kebijakan SVLK itu sendiri. Hal tersebut dapat dilihat pada Permendag Nomor 97/M-DAG/PER/12/2014 yang mengamanatkan dokumen $\mathrm{V}$-Legal wajib untuk panel, woodworking, bangunan prefabs, sebagian pulp dan kertas serta furniture dan kerajinan untuk pelaku usaha besar, dan Deklarasi Ekspor untuk IKM furniture. Pada tahun 2015 diterbitkan Permendag Nomor 89/M-DAG/PER/10/2015 yang menyatakan bahwa Dokumen V-Legal hanya diberlakukan untuk panel, woodworking, bangunan prefabs, sebagian pulp dan kertas, namun tidak untuk furniture dan kerajinan. Kemudian peraturan tersebut direvisi dalam Permendag Nomor 25/M-DAG/PER/4/ 2016, bahwa furniture dan kerajinan wajib $\mathrm{V}$ legal. Peraturan perdagangan dari segi materi terkesan tidak konsisten dalam upaya mendukung SVLK pada industri hilir. Hal tersebut menunjukkan lemahnya koordinasi antar Kementerian dalam mendukung suatu kebijakan terkait bahan baku yang diambil dari hutan dan perdagangannya. Hal lain yang penting adalah penguatan implementasi EU Timber Regulation di seluruh negara EU untuk mendukung pelaksanaan SVLK di sisi pasarnya.

Kenyataan di lapangan menunjukkan bahwa jumlah industri kayu sedang dan besar di Indonesia meliputi industri penggergajian kayu, pengawetan kayu, kayu lapis, kayu lapis laminasi, panel kayu, veneer, barang bangunan kayu, kerajinan dan ukiran serta furniture berbasis kayu sejumlah 1.704 unit (BPS, 2015a). Sedangkan jumlah industri yang telah mendapatkan sertifikat VLK hingga Oktober 2015 baik industri sedang dan besar berjumlah 1.380 unit (SILK, 2015). Hingga tahun 2015, IKM yang telah memiliki SLK total 374 unit. Sebanyak 294 difasilitasi oleh Kementerian LHK, sedang 80 unit difasilitasi Kementerian Perindustrian. Di Daerah Istimewa Yogyakarta (DI Yogyakarta) berdasarkan data Kementerian Perindustrian Jakarta, pada tahun 2014 jumlah industri yang telah menerima SLK berjumlah 17 unit yang tersebar di Sleman, Bantul, Umbulharjo, Gunung Kidul dan Yogyakarta. Sementara pada tahun 2015 menurut Dinas Perindustrian dan Peradagangan DI Yogyakarta, jumlah industri IKM yang sudah memiliki SLK berjumlah 20, dan 2 lainnya sedang dalam proses verifikasi. Sedangkan IUPHHK DI Yogyakarta yang memilki sertifikasi hanya 7 unit (Dinas Kehutanan DI Yogyakarta, 2015)

Industri yang telah memiliki SLK di Jawa Barat berjumlah 81 unit. Dari jumlah tersebut 34 diantaranya terdapat di Kabupaten Cirebon sedangkan sisanya tersebar antara lain di 
Bogor, Bekasi, Purwakarta, Padalarang, Tasikmalaya, Ciamis, Majalengka, Karawang dan Bandung. Di Kabupaten Ciamis, terdapat 98 IKM berbasis kayu yang terdiri atas 6 industri veneer, 18 industri barang bangunan kayu, dan 74 industri furniture (Dinas Koperindag Ciamis, 2015). Namun dari jumlah tersebut, hingga saat ini baru 1 industri yaitu PD. Terus Jaya yang telah memiliki sertifikat VLK yang merupakan indusri hulu (barang bangunan dari kayu), sementara indusri hilirnya belum ada yang memiliki VLK .

Di sisi lain, implementasi SVLK pada hutan rakyat juga belum menunjukkan kemajuan yang berarti. Luas hutan rakyat Indonesia pada tahun 2014 tercatat seluas 34,8 juta ha. Apabila luasan tersebut dibandingkan dengan luas hutan rakyat yang telah disertifikasi pada tahun 2014 yaitu 429.672 ha, maka hutan rakyat yang telah disertifikasi baru mencapai 1,23\%. Di DI Yogyakarta, terdapat 7 (tujuh ) kelompok hutan rakyat yang telah memilik SVLK, antara lain yaitu Koperasi Wana Tunggal (594,15 ha), Serikat Petani Pembaharu Semoyo (251,38 ha),Unit Manajemen Hutan Rakyat (UMHR) Wono Lestari (1.022 ha), Areal Pengelolaan Hutan Rakyat (APHR) Tunas Mekar, Kelompok Tani Hutan (KTH) Jasema, APHR Paguyuban Mitra Wana Binangun dan Koperasi Wana Lestari Menoreh (820 ha). Selain kelompok tersebut, masih terdapat sembilan kelompok hutan rakyat yang dalam taraf pendampingan audit SLK (Dinas Kehutanan DI Yogyakarta, 2015). Di Kabupaten Ciamis, pada tahun 2011 terdapat satu kelompok tani yang telah memiliki sertifikat VLK yaitu Kelompok Tani Sejahtera yang berada di Desa dan Kecamatan Cisaga. Kelompok Tani ini berdiri pada tanggal 15 September 2006 yang beranggotakan sebanyak 54 orang. Dari 60 ha luas hutan rakyat, seluas 15,79 ha telah tersertifikasi. Namun pada tahun 2015 saat kajian ini dilakukan, Kelompok Tani Sejahtera ini tidak lagi mematuhi ketentuan untuk tidak menebang pohon selama masa sertifikasi. Ketua kelompok tidak mampu lagi untuk memberi penjelasan dan melarang anggotanya untuk tidak menebang pohon. Kecenderungan masyarakat anggota kelompok untuk menebang pohon disebabkan antara lain: karena kebutuhan, karena para tengkulak dan pabrik-pabrik disekitarnya tidak menuntut kayu bersertifikat sebagai bahan baku industrinya, dan karena tidak ada jaminan bahwa kayu yang telah memiliki sertifikat VLK akan dibeli dengan harga yang lebih tinggi.

\section{B. Dampak implementasi SVLK terhadap industri dan pengelola hutan rakyat}

Kebijakan SVLK dapat memberikan dampak positif dan negatif bagi industri maupun pengelola hutan rakyat, seperti pada Tabel 3.

Tabel 3. Dampak positif dan negatif pelaksanaan SVLK pada industri dan hutan rakyat

\begin{tabular}{|c|c|c|}
\hline $\begin{array}{l}\text { Industri/petani } \\
\text { (Industry/farmer) }\end{array}$ & $\begin{array}{l}\text { Dampak Positif } \\
\text { (Positive impact) }\end{array}$ & $\begin{array}{l}\text { Dampak Negatif } \\
\text { (Negative impact) }\end{array}$ \\
\hline $\begin{array}{l}\text { Industri sedang dan } \\
\text { besar } \\
\text { (Medium \& big scale } \\
\text { indusytry) }\end{array}$ & $\begin{array}{l}\text { - Mendorong pelaku usaha } \\
\text { untuk tertib izin usaha dan } \\
\text { penatausahaan hasil hutan } \\
\text { - Mendorong untuk tertib } \\
\text { manajemen, sehingga dapat } \\
\text { evaluasi kinerja industri } \\
\text { - Syarat supaya tetap bisa ekspor }\end{array}$ & $\begin{array}{l}\text { - } \quad \text { Belum memberikan nilai tambah yang } \\
\text { signifikan } \\
\text { - } \quad \text { Tambahan biaya (sertifikasi) terhadap } \\
\text { biaya produksi } \\
\text { - } \quad \text { Belum ada peningkatan akses pasar } \\
\text { - } \quad \text { Kebijakan SVLK yang dinamis, membuat } \\
\text { iklim usaha semakin tidak pasti }\end{array}$ \\
\hline
\end{tabular}




\begin{tabular}{|c|c|c|}
\hline $\begin{array}{l}\text { Industri/petani } \\
\text { (Industry/farmer) }\end{array}$ & $\begin{array}{l}\text { Dampak Positif } \\
\text { (Positive impact) }\end{array}$ & $\begin{array}{l}\text { Dampak Negatif } \\
\text { (Negative impact) }\end{array}$ \\
\hline $\begin{array}{l}\text { Industri kecil \&mikro } \\
\text { (small \& micro scale } \\
\text { industry) }\end{array}$ & $\begin{array}{l}\text { Mendorong pelaku usaha } \\
\text { untuk tertib izin usaha dan } \\
\text { penatausahaan hasil hutan } \\
\text { Mendorong untuk tertib } \\
\text { manajemen, sehingga dapat } \\
\text { evaluasi kinerja industri } \\
\text { - Syarat supaya tetap bisa ekspor }\end{array}$ & $\begin{array}{l}\text { - Belum memberikan harga output yang } \\
\text { tinggi } \\
\text { Biaya sertifikasi besar, mensyaratkan } \\
\text { berkelompok memberi dampak tanggung } \\
\text { renteng padahal tiap industri memiliki } \\
\text { tujuan sendiri } \\
\text { - Administrasi memberatkan apalagi SVLK } \\
\text { tidak berdampak terhadap eksistensi } \\
\text { industri khususnya pasar lokal } \\
\text { - Biaya penilikan masih memberatkan } \\
\text { apalagi apalagi Lembaga Penilai dan } \\
\text { Verifikasi Independen (LP \& VI) mayoritas } \\
\text { berada di Jakarta/ibukota propinsi. Jumlah } \\
\text { LP \& VI terdekat masih kurang utamanya } \\
\text { pada daerah penghasil kayu rakyat dan } \\
\text { industri } \\
\text { - Syarat administrasi yang rumit memicu } \\
\text { adanya celah tambahan biaya transaksi } \\
\text { Adanya celah negosiasi auditor dan } \\
\text { industri akan membuat kualitas sertifikasi } \\
\text { kurang baik } \\
\text { Penambahan biaya untuk manajemen / } \\
\text { tenaga industri pengurusan syarat SVLK }\end{array}$ \\
\hline $\begin{array}{l}\text { Petani hutan rakyat } \\
\text { (Private forest } \\
\text { farmers) }\end{array}$ & Legalisasi hutan rakyat & $\begin{array}{l}\text { Petani merasa belum memerlukan SVLK, } \\
\text { yang terpenting adalah bagaimana } \\
\text { memenuhi kebutuhan sehari-hari } \\
\text { Petani masih menganut sistem tebang } \\
\text { butuh untuk mencukupi perekonomian } \\
\text { Biaya sertifikasi besar, mensyaratkan } \\
\text { petani berkelompok memberi dampak } \\
\text { tanggung renteng yang menyulitkan } \\
\text { Belum meningkatkan partisipasi dalam } \\
\text { pelestarian hutan }\end{array}$ \\
\hline
\end{tabular}

Sumber (source): Data primer diolah (Primary data processed)

Persepsi dampak ditanyakan kepada sejumlah pengusaha kecil maupun besar dan kelompok petani yang ada di Jakarta, Ciamis/Tasik dan DI Yogyakarta. Dampak positif yang dirasakan oleh pihak pengusaha industri kecil, sedang, maupun besar adalah memiliki assessment untuk syarat ekspor dan manajemen usaha lebih tertib, sehingga dapat mengevaluasi kinerja industri demi eksistensi industri itu sendiri. Sedangkan dampak yang kurang menguntungkan pengusaha sedang dan besar adalah belum ada penambahan akses pasar dan peningkatan harga output karena menggunakan kayu bersertifikasi.
Selain itu kebijakan yang mudah berubah, dalam waktu yang singkat membuat iklim usaha semakin tidak pasti. Bagi pengusaha kecil dan mikro, pengurangan biaya assessment untuk SVLK berdasarkan PermenLHK Nomor P.96/Menhut-II/2014 perlu disertai dengan persyaratan kelompok yang berdampak secara tanggung renteng bagi semua anggota kelompok masih menjadi kendala. Melihat pengalaman dari negara lain, persepsi beberapa pelaku usaha di Amerika bahwa pertimbangan kompleksitas dan biaya sertifikasi menjadi poin penting untuk tetap mempertahankan keuntungan. Mereka lebih 
peduli bagaimana memperoleh keuntungan kompetitif dan memperluas akses pasar daripada sertifikasi (Montague, 2011)

Persyaratan administrasi yang dibuat pemerintah seyogyanya untuk mengurangi kebocoran produk kayu ilegal. Rumitnya administrasi bagi industri kecil menimbulkan peluang celah untuk penambahan biaya bagi pengurusan SVLK mengekspor produk kayunya, karena tidak diimbangi dengan kapasitas sumber daya manusia (SDM) yang memadai. Apalagi sebagian besar pengusaha kecil ini banyak yang belum memiliki izin usaha sebagai salah satu persyaratan SVLK. Di sisi lain Pratiwi et al. (2015) menyatakan bahwa SVLK memiliki persyaratan administrasi yang lebih sederhana dan murah dibanding Forest Stewardship Council (FSC). Melalui skema FSC mendapatkan jaminan harga produk yang lebih tinggi dari konsumen. Upaya untuk meraih keberhasilan program SVLK diperlukan dukungan Pemda khususnya untuk melakukan sosialisasi tentang masalah perizinan bagi syarat SVLK dan melakukan pendampingan di tingkat petani.

Kebijakan SVLK berlaku baik untuk peredaran barang kayu dalam negeri maupun ke luar negeri. Namun, sejauh ini SVLK tidak berdampak kepada barang kayu untuk permintaan lokal karena konsumen tidak mensyaratkan sertifikasi. Selama ini petani merasa belum memerlukan SVLK, yang terpenting adalah bagaimana memenuhi kebutuhan sehari-hari bagi keluarganya. Penambahan biaya sertifikasi dan rumitnya administrasi menjadi beban yang tidak ringan, sementara tidak ada peningkatan harga kayu rakyat (Nurrochmat et al., 2016). Pemerintah perlu memberikan sosialisasi lebih intensif dan pendampingan agar petani dan usaha kecil dapat mengadopsi kebijakan dengan lebih baik.

Koordinasi pusat ke daerah selayaknya ditingkatkan, mengingat implementasi kebijakan SVLK tidak hanya berdampak terhadap target yaitu industri dan hutan rakyat, tetapi juga memberikan pengaruh kepada pemerintah daerah, yaitu :

- Kebijakan pusat yang mudah berubah berdampak terhadap kurang adanya kepastian dalam pelaksanaan SVLK

- Pemerintah daerah (Pemda) kabupaten/ kota kurang terlibat terkait kewenangan terhadap daerah (UU Nomor 23 tahun 2014), sementara di lain pihak sosialisasi masih terbatas dilakukan.

- Monitoring industri yang telah sertifikasi SVLK belum terealisasi karena Lembaga Penilai dan Verifikasi Indenpen (LP \& VI ) tidak berkoordinasi dengan Pemda (keperluan data base), apakah suatu industri lulus verifikasi atau tidak. Sehingga Pemda belum dapat memantau kegitan SLK di lapangan. Koordinasi antara lembaga verifikasi dan Pemda perlu dilakukan untuk memantau peredaran kayu.

- Tumpang tindih kebijakan pemeriksaan peredaran kayu Surat Keterangan Asal Usul (SKAU) dan SVLK

Secara khusus kajian ini juga melihat bagaimana dampak penambahan biaya sertifikasi pada industri mikro, kecil, sedang dan besar yang didasarkan klasifikasi industri atas jumlah tenaga kerja (berdasarkan klasifikasi Badan Pusat Statistik/BPS) terhadap biaya input industri. Pelaksanaan SVLK memberi dampak baik kepada industri sedang besar, kecil dan mikro. Industri sedang dan besar kayu yang menjadi sample meliputi: industri pengergajian kayu, industri pengawetan kayu, industri kayu lapis, industri kayu lapis laminasi, industri veneer, industri barang bangunan kayu, industri kerajinan dan ukiran kayu serta industri mebel kayu di Indonesia. Penambahan biaya sertifikasi pada industri sedang besar (sesuai PermenLHK Nomor P.96/Menhut-II/2014) memberikan dampak penambahan biaya kurang lebih 3\% dari keseluruhan biaya input (lihat Gambar 2).

Biaya input adalah adalah biaya produksi di luar biaya tenaga kerja antara lain bahan 


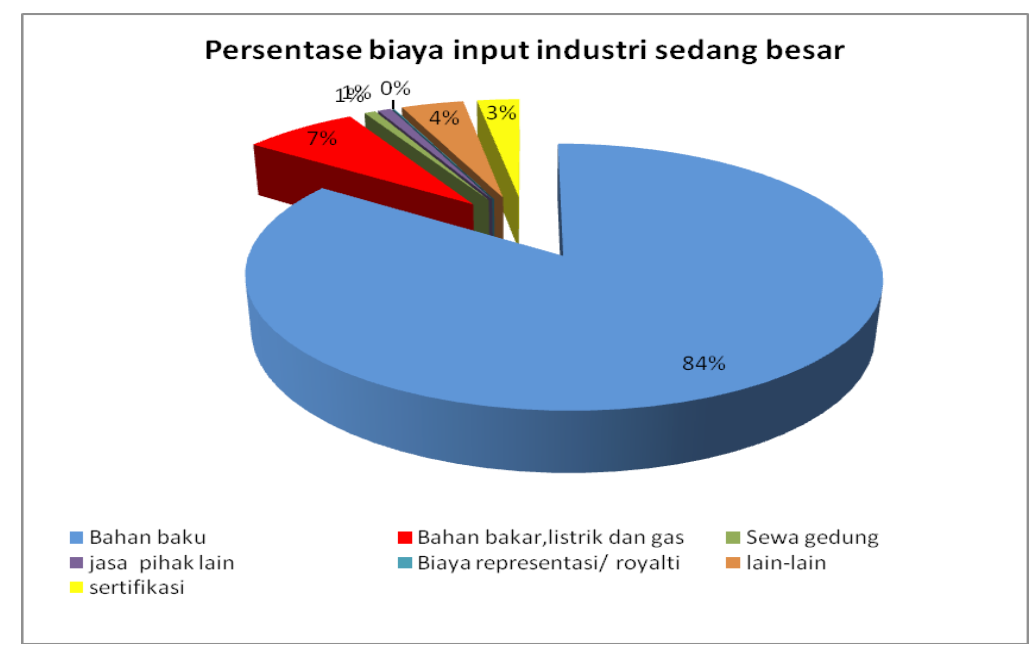

Sumber (Source): BPS, 2015a

Gambar 2. Komposisi biaya input industri sedang dan besar Figure 2. Composition of input cost medium and large industrial

baku dan penolong, bahan bakar, sewa gedung, jasa pihak lain, biaya representatif dan lain-lain (BPS, 2015b). Adanya biaya sertifikasi akan menambah komponen dalam biaya input. Biaya yang paling besar adalah biaya bahan baku dan penolong yaitu $84 \%$. Bahan penolong merupakan bahan yang diperlukan dalam proses produksi (jumlah relatif sedikit), namun bukan merupakan bagian dari bahan baku utama untuk produk yang dihasilkan. Adanya penambahan biaya sertifikasi pada biaya input industri sedang dan besar hanya 3\%. Dari segi ekonomi biaya sertifikasi ini tidak memberatkan industri sedang besar (Astana et al., 2014), adanya SVLK memudahkan untuk menjaring buyer dan mengikuti pameran di luar negeri yang pada akhirnya akan meningkatkan permintaan (Salam et al., 2015)

Dampak implementasi kebijakan SVLK juga dirasakan oleh industri kecil dan mikro (lihat Tabel 4). Untuk industri mikro dan kecil furniture penambahan biaya sertifikasi relatif kurang berpengaruh, karena biaya sertifikasi hingga 5,6\%. Penambahan biaya sertifikasi pada industri mikro/rumah tangga Rp6.663.800 akan menambah biaya sebesar $25,3 \%$ pada industri kayu.
Asumsi yang digunakan untuk menghitung biaya sertifikasi merujuk ketentuan PermenLHK Nomor P.96/Menhut-II/2014. Adanya penambahan biaya sertifikasi pada biaya input industri sedang dan besar diperkirakan hanya 3\%. Dari segi ekonomi tentang biaya sertifikasi ini tidak memberatkan industri sedang dan besar. Eksistensi industri sedang dan besar tidak terpengaruh oleh penambahan biaya sertifikasi. Untuk industri mikro furniture penambahan biaya sertifikasi relatif kurang berpengaruh, karena besaran biaya sertifikasi bisa mencapai 5,6\%. Penambahan biaya sertifikasi pada industri mikro/rumah tangga akan menambah biaya sebesar 25,3\% pada industri kayu dan industri hasil hutan lainnya. Dampak biaya sertifikasi paling berpengaruh pada industri mikro kayu dalam hal ini industri penggergajian, bahan bangunan dan kerajinan.

Sementara itu kalau melihat pengalaman sertifikasi kayu di Korea, kurang lebih $(77,2 \%)$ menyatakan kesediaan mereka untuk membeli kayu bersertifikat produk. Mayoritas responden bersedia membayar produk kayu bersertifikat yaitu kurang dari 5\% (premium price)(Cha \& Chun, 2009). Hal ini menunjukkan bahwa konsumen tidak 
Tabel 4. Persentase biaya sertifikasi terhadap biaya input industri mikro dan kecil.

Table 4. Percentage of certification to input cost on micro and small industry

\begin{tabular}{lrrrr}
\hline & \multicolumn{2}{c}{$\begin{array}{c}\text { Industri kayu } \\
\text { (wood industry) }\end{array}$} & \multicolumn{2}{c}{$\begin{array}{c}\text { Furniture } \\
\text { (Furniture) }\end{array}$} \\
\cline { 2 - 5 } & Mikro (micro) & Kecil (small) & Mikro (micro) & Kecil (small) \\
\hline Jumlah industri (unit) & 784.753 & 20.723 & 122.182 & 19.475 \\
\hline Nilai input (Rpx1.000.000) & 15.473 .068 & 7.784 .568 & 13.855 .047 & 14.741 .387 \\
\hline $\begin{array}{l}\text { Biaya } \text { input per-unit industri } \\
\text { (Rp) }\end{array}$ & 19.717 .118 & 375.648 .699 & 113.396 .793 & 756.938 .998 \\
\hline Biaya sertifikasi (Rp) & 6.663 .800 & 10.060 .600 & 6.663 .800 & 10.060 .600 \\
\hline $\begin{array}{l}\text { Persentase biaya sertifikasi } \\
(\%)\end{array}$ & & & & \\
\hline
\end{tabular}

Sumber (Source): Data sekunder diolah dari BPS, 2015 (Secondary data processed from BPS, 2015)

akan membeli lebih mahal 5\% dari kayu non sertifikat. Sehingga apabila penambahan biaya input lebih dari $5 \%$ pada produk bersertifikat SVLK yang akan berimbas terhadap harga output, tentu konsumen tetap lebih memilih kayu yang tidak bersertifikat.

Sebagian besar usaha IKM di Indonesia pada tahun 2015 mengaku mengalami kesulitan dalam menjalankan usahanya yaitu $73,96 \%$. Kesulitan utama yang dirasakan oleh usaha kecil adalah kesulitan modal usaha $38,84 \%$, kesulitan pemasaran hasil usaha $25,00 \%$, dan kesulitan bahan baku 22,29\% (BPS, 2015). Harapan IKM ke depan dengan adanya SVLK akan membuka pintu pasar yang baru. Kesulitan utama industri furniture kayu adalah keterbatasan bahan baku kayu khususnya kayu jati untuk mebel (Nasikh, 2009). Kendala utama IKM belum sepenuhnya terselesaikan, apalagi jika ditambah dengan persyaratan SLK, sehingga bantuan fasilitasi stakeholder sangat dibutuhkan. Kesulitan pemasaran karena kualitas produk dan kegiatan promosi relatif rendah sehingga sulit untuk bersaing di pasar internasional. Masalah lain adalah kurangnya informasi mengenai peraturan dan peluang untuk masuk ke pasar internasional. Hal ini diduga karena permasalahan sumber daya manusia (SDM). Sehingga pendampingan perlu dilakukan hingga industri tersebut mandiri dalam bentuk asosiasi industri maupun koperasi hutan rakyat. Seperti APIKRI yaitu Asosiasi Industri Kayu, Kerajinan dan Meubel di DI Yogyakarta yang dapat membantu kesulitan pengusaha/pengrajin baik dari sisi ekonomi sekaligus kelembagaannya.

Dampak SVLK terhadap hutan rakyat juga dapat dilihat dari komponen biaya sertifikasi dan penilikan terhadap total biaya pembuatan hutan rakyat. Tabel 5 menunjukkan biaya input hutan rakyat berdasarkan Keputusan Kepala Pusat Pembiayaan Pembangunan Hutan Nomor SK.16/P2H-1/2012 tentang Biaya per Pohon untuk Pembiayaan dan Pinjaman Pembuatan/Pengayaan dan Pemeliharaan Hutan Rakyat dan hasil wawancara dengan Kelompok Tani Sejahtera di Ciamis dengan asumsinya dalam 1 ha terdapat 500 pohon sengon rakyat.

Kelompok Tani Sejahtera, Desa Cisaga Kabupaten Ciamis memiliki luas 15,79 ha dengan jumlah anggota 54 orang, sehingga rata-rata kepemilikan lahan petani 0,3 ha. Kelompok tani ini awalnya adalah cikal bakal Pengelolaan Hutan Bersama Masyarakat (PHBM) yang digulirkan oleh Perum Perhutani Ciamis tahun 2004. Selanjutnya kelompok tani ini difasilitasi oleh The International Tropical Timber Organization (ITTO) dan Dinas Kehutanan Kabupaten Ciamis. Kelompok tani ini telah dibina kegiatan pembibitan, pembuatan bokashi, pendataan potensi lahan dan persemaian. Tanaman utama adalah 
Tabel 5 Biaya sertifikasi dan biaya input pembuatan hutan rakyat

Table 5. The certification costs and input costs to build private foresty

\begin{tabular}{lrr}
\hline $\begin{array}{c}\text { Biaya hutan rakyat1 daur (6 tahun) } \\
\text { (private forest cost (6 year)) }\end{array}$ & $\begin{array}{c}\text { SK.16/P2H-1/2012 } \\
\text { (Financing regulation of } \\
\text { plantation)/Rp }\end{array}$ & $\begin{array}{c}\text { Kelompok petani } \\
\text { (Group of farmers) } \\
\text { "Tani Sejahtera"/Rp }\end{array}$ \\
\hline Biaya input hutan rakyat/ha(1 daur 6 tahun) & 21.450 .000 & 23.250 .000 \\
\hline Biaya input kelompok tani sejahtera & 338.674 .050 & 367.094 .250 \\
\hline Biaya sertifikasi sampel <25 orang & 15.984 .000 & 15.984 .000 \\
\hline Biaya penilikan & 36.774 .000 & 36.774 .000 \\
\hline Total sertifikasi dan penilikan & 52.758 .000 & 52.758 .000 \\
\hline Biaya sertifikasi+penilikan /biaya input (\%) & 15,58 & 14,37 \\
\hline
\end{tabular}

Sumber (source): Data primer diolah (Primary data processed)

sengon selebihnya adalah sedikit jati, mahoni dan tanaman buah-buahan. Apabila biaya sertifikasi Rp15.984.000/kelompok, maka untuk setiap kelompok tani tersebut terkena biaya tambahan rata-rata $15 \%$ dengan asumsi terdapat biaya penilikan setiap 2 tahun. Biaya ini termasuk relatif rendah karena ditanggung secara bersama-sama oleh kelompok. Namun bagi petani penambahan biaya berapun nilainya apabila tidak meningkatkan harga output dianggap tidak menarik. Karena selama ini sumber penghasilan masyarakat tergantung pada hutan rakyat.

Keberadaan SVLK belum memberikan dampak berupa harga output yang lebih tinggi dan belum berpengaruh terhadap kelestarian hutan rakyat. Pemasalahan hutan rakyat masih mendasar menganut sistem tebang butuh untuk menyokong kehidupan seharihari. Hal yang senada juga ditemukan pada kelompok tani hutan rakyat di Jawa Tengah bahwa dengan masyarakat merasa tidak diuntungkan dengan adanya SVLK (Erbaugh et al., 2016). Keberadaan SVLK juga tidak dapat menjawab kebutuhan mereka. Secara ekonomi, sertifikasi SVLK untuk hutan rakyat adalah logika yang aneh dan bisa mengurangi luasan hutan rakyat di pedesaan (Nurrochmat et al., 2014)

Petani di Jawa Barat dan DI Yogyakarta memilikikesamaanyaitumemilikipemahaman yang terbatas tentang SVLK apalagi rata-rata adalah petani berpendidikan rendah yang tidak memungkinkan untuk membuat peta lokasi tanaman hutan rakyat dan memenuhi syarat SVLK, sehingga pendampingan adalah syarat mutlak yang diperlukan oleh petani. Selain itu, petani tidak akan berubah pendiriannya atau pemahamannya jika tidak mendapatkan insentif yang nyata dirasakan. Sosok dan komitmen ketua kelompok memengaruhi anggotanya sehingga pada umumnya akan lebih efektif apabila ketua kelompok tani adalah pengurus desa atau pemuka agama yang disegani.

Di sisi lain bagi industri kecil dan mikro, adanya beban biaya sertifikasi SVLK tanpa memperoleh premium price (dari konsumen) berpotensi membuat industri tutup dan menjadi konsekuensi negatif lebih lanjut bagi petani. Tidak hanya di Indonesia, bahkan di Rusia pun, sertifikasi hutan belum memberikan manfaat yang positif bagi masyarakat dan industri kecil dan menengah. Sertifikasi telah mengakibatkan perusahan kecil dan menengah tutup dan masyarakat lokal kehilangan akses untuk kayu gergajian serta harga kayu bakar menjadi meningkat (Tysiachniouk \& McDermott, 2015). Sebelumnya Lesniewska \& McDermott (2014) menyatakan bahwa penerapan kebijakan yang sama antara industri berskala ekspor dengan industri kecil, justru akan membatasi partisipasi masyarakat sipil dan menciptakan hambatan pasar (barrier) 
yang tidak proporsional bagi produsen lokal yang berskala kecil.

Tujuan pemerintah Indonesia untuk membangun suatu alat verifikasi legalitas yang kredibel dan efisien sebagai salah satu upaya mengatasi persoalan pembalakan liar dan peningkatan daya saing produk kehutanan merupakan awal yang baik. Upaya untuk mencapai tujuan tersebut akan tercapai apabila sertifikasi diberlakukan secara adil berdasarkan skala usaha industri dan pangsa pasarnya.

\section{KESIMPULAN DAN SARAN}

\section{A. Kesimpulan}

Terdapat disharmoni antara kebijakan yang dikeluarkan Kementerian LHK dan Kementerian Perdagangan, hal ini diduga merupakan penyebab hambatan dalam implementasi SVLK. Kebijakan SVLK, baik yang dikeluarkan oleh pemerintah (Kementerian LHK maupun Kementerian Perdagangan) menunjukkan perubahan yang cepat, sementara pengguna kebijakan (industri dan hutan rakyat) tidak dapat mengikuti secara cepat perubahan tersebut dalam penerapan SVLK di lapangan. Perubahan kebijakan yang cepat menunjukkan adanya permasalahan sebelum kebijakan tersebut diimplementasikan yaitu saat proses formulasi kebijakan maupun tahap adaptasi kebijakan yang disertai dengan pendampingan. Regulasi terkait SVLK umumnya masih parsial dan tidak terintegrasi, dimana regulasi yang dikeluarkan oleh Kementerian LHK lebih difokuskan pada pengelolaan hutan dan berusaha mengurangi hambatan untuk industri kecil baik segi biaya maupun teknis. Sementara kebijakan di hilir yang merupakan ranah Kementerian Perdagangan cenderung melemahkan kebijakan SVLK. Walaupun pada akhirnya direspon dengan kebijakan yang mendukung SVLK termasuk bagi industri mebel. Pelaku usaha memerlukan government consistency dalam penentuan kebijakan yang ditetapkan dalam menjamin kepastian usahanya.

Kebijakan untuk mendukung implementasi SVLK telah banyak digulirkan akan tetapi jumlah industri dan hutan rakyat yang bersertifikat SVLK masih relatif sedikit. Belum banyak dampak positif yang dirasakan oleh industri maupun petani hutan rakyat setelah pelaksanaan SVLK. Pemberlakuan SVLK membuka akses ekspor dan mendorong pelaku usaha untuk tertib usaha, tetapi SVLK belum mampu menjadi insentif pasar bagi pemilik SVLK tersebut. SVLK belum mampu memberikan peningkatan harga output (premium price). Bagi industri kecil/mikro (syarat kelompok dan dampak tanggung renteng masih memberatkan), SVLK belum memberikan akses pasar yang baru, administrasi memberatkan, apalagi kepemilikan sertifikat SVLK juga tidak berdampak terhadap eksistensi industri khususnya pasar lokal, inefisiensi biaya penilikan karena Lembaga Penilai dan Verifikasi Independen (LPVI) mayoritas berada di Jakarta/ibukota provinsi, dan syarat administrasi yang rumit.

Petani merasa belum memerlukan SVLK, yang terpenting adalah bagaimana memenuhi kebutuhan sehari-hari. Karena biaya sertifikasi yang cukup besar bagi petani, maka petani disyaratkan untuk berkelompok dalam mengajukan sertifikasi yang memiliki dampak tanggung renteng bagi anggota kelompok taninya. Secara umum SVLK juga belum dapat meningkatkan partisipasi dalam pelestarian hutan. Berdasarkan fakta pada tingkat kelompok tani, kebijakan SVLK pada hutan rakyat dan perdagangan kayu di tingkat lokal belum efektif.

Penambahan biaya sertifikasi terhadap biaya input tidak memberatkan bagi industri sedang, besar, dan kecil, tetapi memberikan dampak yang memberatkan bagi industri mikro. Biaya lain yang lebih memberatkan adalah biaya untuk memenuhi persyaratan SVLK yaitu segala macam perizinan industri. Kesulitan utama IKM belum sepenuhnya terselesaikan dari segi modal 
usaha, pemasaran, dan kesulitan bahan baku, sehingga implementasi SVLK di tingkat yang paling rendah masih menemui hambatan. Pembentukan asosiasi atau koperasi untuk industri kecil dipandang sebagai salah satu solusi yang baik dari sisi ekonomi maupun kelembagaan.

\section{B. Saran}

Peningkatan koordinasi antara Kementerian LHK dan Kementerian Perdagangan diperlukan bagi implementasi yang lebih baik. Selain itu perlunya dukungan Kementerian Koperasi dan UKM melalui fasilitasi untuk peningkatan kapasitas/pendampingan di lapangan terhadap kelembagaan Koperasi Unit Desa (KUD) yang berkualitas sebagai lembaga Sertifikasi Kelompok Hutan Rakyat, IKM, industri mikro/rumah tangga. Dukungan tersebut juga diperlukan dari pemerintah daerah dalam bentuk fasilitasi dalam hal perizinan sebagai syarat SVLK. Untuk efisiensi SVLK, diperlukan Lembaga Verifikasi dan Legalitas Kayu (LVLK) pada daerah sentra industri dan daerah penghasil bahan baku kayu rakyat (hutan rakyat).

\section{UCAPAN TERIMA KASIH (ACKNOWLEDGMENT)}

Penulis mengucapkan terima kasih kepada Kepala Dinas Kehutanan DI Yogyakarta, Kepala Dinas Kehutanan Kabupaten Ciamis, kepala Dinas Perindustrian, Perdagangan dan Koperasi DI Yogyakarta, Kepala Dinas Perindustrian dan Perdagangan Ciamis serta Pusat Penelitian dan Pengembangan Sosial, Ekonomi, Kebijakan dan Perubahan Iklim yang telah membantu dalam kegiatan penelitian ini.

\section{DAFTAR PUSTAKA}

Anderson, J. E. (2003). (2003). Public policy making : An introduction. Boston: Houghton Mifflin Company.

Astana, S., Obidzinski, K., Riva, W.F., Hardiyanto, G.,
Komarudin, H., \& Sukanda. (2014). Implikasi biaya dan manfaat pelaksanaan SVLK terhadap sektor perkayuan skala kecil. Jurnal Penelitian Sosial dan Ekonomi Kehutanan, 11(3), 175-198.

BPS. (2015). Profil industri mikro dan kecil. Jakarta: Badan Pusat Statistik.

BPS. (2015a). Jumlah industri dan biaya input industri sedang dan besar. Jakarta: Badan Pusat Statistik

BPS. (2015b). Konsep perusahaan industri pengolahan. Jakarta: Badan Pusat Statistik.

Cha, J., \& Chun, J., YeoChang, Y. (2009). Consumer willingness to pay price premium for certified wood products in South Korea, Jour. Korean For. Soc. 98(2), 203-211.

Dinas Kehutanan DI Yogyakarta. (2015). Monev implementasi SVLK di DI Yogyakarta. Yogyakarta: Dinas Kehutanan DI Yogyakarta..

Dinas Koperindag Ciamis. (2015). Profil industri kayu di Kabupaten Ciamis. Ciamis: Dinas Koperindag Ciamis.

Dye, T. R. (2008). Understanding public policy (12th ed.). United States: Prentice Hall.

Effendi, R. (2011). The study of marketing channel of the community timber. Jurnal Penelitian Hutan Tanaman, 8(4), 251-258.

Gultom, M., Astana, S., Effendy, R., \& Kurniawan, A. S. (2014). Sistem verifikasi legalitas kayu dan perbandingannya dengan sertifikasi sukarela pada level industri. Jurnal Analisis Kebijakan Kehutanan, 11(3), 261-275.

Kementerian Perindustrian. (2015). Hambatan sertifikasi SVLK bagi IKM. Jakarta: Kementerian Perindustrian.

LAN. (2008). Analisis kebijakan publik. Jakarta: LAN. Lesniewska, F., \& McDermott, C. L. (2014). FLEGT VPAs: Laying a pathway to sustainability via legality lessons from Ghana and Indonesia. Forest Policy and Economics, 48(1), 16-23. https://doi.org/10.1016/j.forpol.2014.01.005

Montague, I. B. (2011). Understanding chain-ofcustody certification in the Appalachian Hardwood Region : Primary manufacturers' practices and perceptions.. Proceedings of the 17th Central Hardwood Forest Conference. Lexington, KY April 5-7, 2010. Newton Square: USDA Forest Service.

Nasikh. (2009). Model optimalisasi faktor produksi usaha industri kecil mebel kayu jati di Pasuruan Jawa Timur. Jurnal Manajemen dan Kewirausahaan, 11, pp.85-93. 
Nurrochmat, D. R., Darusman, D., \& Ekayani, M. (2016). Kebijakan pembangunan kehutanan dan lingkungan: Teori dan implementasi (Cetakan I). Bogor: Penerbit IPB Press.

Nurrochmat, D. R., Dharmawan, A. H., Obidzinski, K., Dermawan, A., \& Erbaugh, J. T. (2014). Contesting national and international forest regimes: Case of timber legality certification for community forests in Central Java, Indonesia. Forest Policy and Economics. https://doi.org/10.1016/j.forpol.2014.09.008

Nurrochmat, D.R., Hasan, M.F., Suharjito, D., Hadianto, A., Ekayani, M., Sudarmalik, ... Ryandi, E. (2012). Ekonomi politik kehutanan: Mengurai mitos dan fakta pengelolaan hutan . (Nurrochmat, D.R. \& Hasan, M. Eds.).. Jakarta: INDEF

Pratiwi, S., Wibowo, A., \& Giessen, L. (2015). Thirdparty certification of forest management in Indonesia: Analysing stakeholders' recognition and preferences. Jurnal
Manajemen Hutan Tropika (Journal of Tropical Forest Management), 21(2), 65-75. https://doi.org/10.7226/jtfm.21.2.65

Salam, A.S., Purwanto, \& Suherman. (2014). Penerapan V-legal pada industri furnitur kayu di Jepara sebagai upaya meningkatkan nilai jual produk. Jurnal Ilmu Lingkungan, 12(1), 32-41.

SILK. (2015). Data industri SLK. (Laporan). Jakarta: SILK.

Susilowati, D. (2014). Evaluasi sistem verifikasi legalitas kayu (SVLK) dan praktek lokal di hutan rakyat. (Materi Pelatihan Pusdiklat Kehutanan). Bogor: Pusdiklat Kehutanan.

Tysiachniouk, M., \& McDermott, C. L. (2015). Certification with Russian characteristics: Implications for social and environmental equity. Forest Policy and Economics, 62, 43-53. https://doi.org/10.1016/j. forpol.2015.07.002 